\title{
La guerra atacameña del siglo XVI: Implicancias y trascendencia de un siglo de insurrecciones indígenas en el despoblado de Atacama
}

\section{La conquista hispana de Atacama: Episodio marginal de la Conquista}

Los adelantos hispanos que a partir de 1535 se asignaron la tarea de allanar para el Imperio las todavía anónimas comarcas del mediodía chileno, vislumbraron en el Desierto de Atacama una frontera, en principio, desdeñable. Ese austero pasillo, ocupado en parte por la "nación Atacama", gentilicio que sin mucho acierto impusieron a ésta caudillos y cronistas ${ }^{1}$, representó para las primeras lanzas de la Conquista mero espacio de tránsito, el impreciso distrito fronterizo que señalaba la vaga divisoria jurisdiccional entre Chile y Perú (Lizárraga 1968: 50; Alcedo y Herrera 1786, I: 272-273; Marino de Lovera 1595, CHCH, VI: 38-39; Góngora y Marmolejo 1575; CHCH, II: 5; Garcilaso de la Vega 1609, CHCH, XXIX: 294-297; Valdivia 1547: 87, 1550: 148149, 195). La sujeción inmediata de los reductos fértiles del borde de la Puna, del Salar de Atacama y de las amenas vegas del Loa, constituyó para las respetables mesnadas ibéricas, que a partir de 1536 asumieron el mandato de cautivar el mundo andino meridional, un reto prescindible. No obstante que la calzada desértica comportó uno de los canales de transición y enlace con la jurisdicción chilena, y de que su entidad aborigen asedió con la guerra a las primeras divisiones españolas que desafiaron el ascético paisaje atacameño, hasta las medianías del siglo el despoblado figuró como espacio marginal respecto a las tentativas sujecionales que los hispanos promovieron en su entorno. Constituyó, al par, una frontera de

1 El expediente seguido contra el encomendero Juan Velásquez Altamirano en 1591 revela que este calificativo étnico era ya de uso universal entre los españoles del partido (ANB, Audiencia de Charcas, Sección Expedientes, Leg. 417, Atacama la Grande 19 de julio de 1591, Información sobre pescado que los indios del puerto de la Magdalena llevaban a Potosí por orden de su corregidor). Previamente, el Factor de Potosí, Juan Lozano Machuca, empleó igual designación en su carta al virrey Martín Enríquez, en 1581 (Lozano Machuca 1581: 61). fricción y un rezago de la dominación europea en la periferia sur del virreinato.

Bien es cierto que las huestes de Almagro y Valdivia practicaron las representaciones de estilo ante el antagonismo comarcano e, incluso, la segunda decretó una ligera pacificación, mas ni los grandes adalides peninsulares ni los altos mandos virreinales alentaron una expansión de monta o una anexión bélica sistemática espaldada por el núcleo metropolitano que, tal vez, hubiera omitido al Imperio 20 años de fatigas y de sangre.

Una concisa mirada basta para columbrar la situación de insularidad a que la confinó este proyecto tangencial del Estado. En tanto hacia 1550 las refundaciones urbanas y las tareas de pacificación alternativas ganan definitivamente para el César el territorio de Copiapó al sur y la irrupción hispana progresa en la lindante región tarapaqueña, merced a la ocupación incruenta en sus hábitats fértiles, las partidas atacameñas aún empeñan su asedio a las expediciones y establecimientos ibéricos de los oasis pedemontanos, como en sus días más felices.

Por cierto, la anexión política consumada en 1557 no comportó la enmienda radical del cuadro de relegación regional. El distrito de Atacama prosiguió ligado a su destino insular, todavía en los períodos que contemplaron su capitulación irreversible ante la dominación castellana. No logró revertir la posición subalterna a que lo postergaron las directrices geopolíticas asumidas por la colonización hispana en el dominio árido, preterición que tiene en las orientaciones adoptadas en las jurisdicciones inmediatas un crudo testimonio. Los dignatarios de Perú enfatizaron su gestión reguiadora en Pica, Iquique y Puerto Loa, en lo que al sur de la demarcación ariqueña concierne, los de Potosí levemente valoraron los territorios de sus comarcas eriales del occidente andino como límite estimable, al par que los peninsulares de Chile fueron tenuemente motivados por las regiones septentrionales de Copiapó (Villalobos 1974). 
La irrupción peninsular, de consiguiente, careció de corpulencia. Se limitó, en el decurso del siglo XVI y en el siguiente, a la pausada constitución de una somera capa de ibéricos, residenciados principalmente en San Pedro de Atacama y Chiu Chiu o dispersos en las aldeas de los ayllus aledaños. Descontada la figura indispensable de la escueta facción burocrática, la presencia de los encomenderos y sus linajes, algunos oficiales, doctrineros y de los exiguos mercaderes, mineros, terratenientes y vecinos, asistidos por sus esclavos y sirvientes, representó todo el sustrato de una sociedad hispana comarcal que discurrió constreñida por el robusto predominio del indio (Casassas 1974).

El espacio atacameño fue, en principio, orillado por la conquista directa. Ni las expediciones de Almagro y Valdivia conllevan ese mandato; de otra parte, el Estado hispano medió escuetamente en su incautación, hecho que parece más un proceso privativo que acto de estado. Como quiera que fuese, la sociedad de la Conquista no arraigó sino a los fines del siglo XVI, tras debatirse en los avatares de media centuria de rebeliones indígenas.

Mas, no será enfatizando en los lineamientos empíricos o en el sesgo sociológico explícito que singulariza el afianzamiento de la sociedad castellana dominante, sino en la vitalidad organizacional en que descansa la entidad étnica preocupante, que una exégesis, acaso más lúcida del momento irruptivo hispano y su impacto, se volverá plausible.

De consiguiente, la consistente ponderación del episodio subvertivo indigenal se tornará hacedera escrutando en la vertiente secular del universo nativo, peculiarmente en la trama organizativa que particulariza a la etnia atacameña en el vasto horizonte étnico vigente en lo que fuera el linde meridional del Imperio inca, coetáneamente al arribo castellano.

\section{Etnia atacameña y conquista hispana}

La robusta resistencia que la etnia atacameña desplegó frente a las huestes españolas que solieron discurrir por la ascética calzada del desierto, no bien el Mariscal Almagro y sus pares develaron aquella ruta para la conquista, denota que la hegemonía impuesta por el Tawantinsuyo sobre las entidades nativas de los valles subandinos, en los 70 años que preceden a la irrupción castellana, no menoscabó el vigor orgánico de la Cultura San Pedro; ese cultivado universo de los "arquitectos de aldeas", incierto eufemismo que invoca a las gentes de una cultura cuyo alto abolengo andino reposaba en un tenaz trayecto histórico; dueña, hacia la época de Almagro, de un pretérito que desbordaba los dos milenios de historia (Orellana 1963; Bittmann et al. 1978).

Ya hacia los 900 DC y restando más de 600 años para el instante en que habría de consumarse la conquista inca, la sociedad amerindia que imperaba en los hábitats agrarios preandinos del ámbito circumpuneño hacía ingreso a un episodio de mayor definición étnica, afincada en el sólido contenido etnocultural depositado por las fases ya consuntas. La etapa embrionaria e iniciática (500 AC-300 DC), y la de floración cultural (300-900 DC), capítulo este último que coincide con el copioso flujo aculturativo emanado hacia la cinta de oasis atacameños desde el altiplano nuclear (Tiwanaku) (Núñez 1965; Willey 1971; Ponce 1976), forjaron una coherente tendencia interna hacia la autoidentificación cultural, que la vasta etapa post Tiwanaku, concluyó por enfatizar.

El Período Tardío, frontera temporal de la etapa ulterior de la Cultura San Pedro, se vive en los oasis subandinos como un vigor inmanente orientado francamente hacia la planificación de la etnia atacameña, proceso de particularización etnográfica que encuentra expresión en la consolidación de un estatus privativo de la cultura.

La maduración de la estructura sociopolítica de sesgo señorial, el predominio ejecutivo de una élite autoritaria territorial, o la estabilización de los logros agropecuarios vallunos, del tráfico multiétnico y del control multiecológico, en una amplia gradiente altitudinal, marchan al par que la singularización que se observa en el dominio lingüístico (primacía del kunza), costumbrista e ideológico-cultista (consolidación del ideario mágico religioso y de prácticas rituales).

En la demarcación atacameña ese proceso marchó en avenencia con la distinción étnica que la etnia Atacama consuma respecto a los colindantes étnicos aymara el Altiplano Meridional y la hegemonía interna que los señores comarcanos establecen en el verde ámbito de los valles fluviales, en los que una breve élite señorial pasó a imperar sobre los espacios productivos, redistribuyendo territorios étnicos, ayllu, aldeas dispersas y ciudadelas fortificadas (Bittmann et al. 1978). La pluralidad de señoríos que fraccionan entonces el fecundo escenario del Loa, del Salar y quebradas interiores, delimita sus 
respectivos focos regionales acentuando la conducta defensiva en lo concerniente a sus espacios étnicos pertinentes, mediante el robustecimiento de un sistema fortificatorio en cerros, expresado en la línea de pucaras que amparan ayllu y campos de cultivos, al tiempo que los notables de Atacama estrechan su vinculación con la periferia andina (Silva 1980).

La preeminencia de los señores naturales no puede disociarse del quebrantamiento radical de la hegemonía Tiwanaku (1000 DC), y la consiguiente reordenación política del cuadro panandino meridional a través de unidades étnicas autónomas, que privilegian la actuación de poderes señoriales internos (Núñez et al. 1978).

En Atacama adquieren vigencia las tendencias sociopolíticas propias de la sociedad tardía meridional que en el Norte Grande soportó la fase de los Desarrollos Regionales, ya en la etapa de post Tiwanaku (Bittmann et al. 1978). No obstante que la tarea colectiva de expandir y consumar técnicamente una agricultura de riego canalizado (maíz) sugiere desde ya la constitución de una conducción autoritaria consistente (Silva 1974), la ordenación señorial a la que se arrojó la sociedad atacameña tardía promovió el afianzamiento de una élite rectora que vigorizó sus prerrogativas de presión social en sintonía con la reclasificación política del panorama andino meridional post Tiwanaku (Bittmann et al. 1978).

No es improbable que la organización de ayllu continuara representando la instancia base de la trama socioproductiva local (Villalobos 1980). Se conjetura, en todo caso, que las unidades espaciales patrimoniales de cada señorío étnico descansan sobre un delimitado horizonte social y territorial, integrado por una diversidad de ayllu con sus respectivos linajes consanguíneos, sus predios agropastoriles comunitarios y sus núcleos aldeanos (Silva 1980).

El predominio de tales rasgos presupone el diseño de una estructura sociológica de cierto contenido jerárquico y la gestión reguladora de una élite embrionaria en el plano organizacional (Hidalgo 1982a). El control señorial sugiere una franca intervención de esa élite incipiente en el ámbito de las relaciones reciprocitarias locales, amén de la capacidad de mediar privilegiadamente en la redistribución de bienes y servicios gestados comunitariamente.

La consecución por mandos y élite de un acceso privativo a recursos agroganaderos (p.e., el usufructo de bosques de algarrobo o el goce de servicios adicionales, ergo trabajo comunitario de sus tierras) es un diáfano testimonio de esa tendencia social (Hidalgo 1982a). Es plausible que a nivel de familias nucleares la voz del campesino tuviera resonancia entre los voceros filiales de cada ayllu o en el Consejo de Mayores, como bien se ha avanzado (Mostny 1954; Villalobos 1980), pero sería una divagación sin destino presumir que, más allá de la estrecha frontera familiar, ambas instancias de representación se encontraban en pie de regular con acierto toda la compleja red de nexos corporativos.

En aquellos delgados distritos agrarios cercados por la silueta tenaz del desierto, los derechos individuales quedaron inexorablemente sujetos a límites e imposiciones sociales. La organización de empresas ecuménicas, de las tareas corporativas o la resolución de diferendos internos gestados en torno al control de espacios, manantiales y bienes diversos, propugnaban la actuación de una dirección autoritaria capaz de regularlas y de orientarlas (Hidalgo 1980a). Al arribo de la primera hueste castellana, un caudillo señorial prevalecía, tal parece, sobre la diversidad de señores naturales del desierto. Debió ostentar ciertas prerrogativas ejecutivas y proyectar la sombra de un prestigio venerable como para acaudalar, por más de 20 años, a los varios notables comarcanos y a la anónima masa indiana en una guerra dilatada en la que se decidió y perdió el destino de los suyos.

Varios rasgos denuncian que esa autoridad no era unipersonal.

Los dignatarios castellanos que solieron frecuentarlo con ocasión de las paces de 1557 develaron la presencia adjunta de diez principales comarcanos evocados por sus gentilicios respectivos, como si éstos gozaran de un rango y crédito más estimable que el pleno de los notables territoriales, los cuales son citados, únicamente, como contingente anónimo. Los escribanos iberos, a tal efecto, acreditan que en las tratativas de 1557 los dignatarios peninsulares gestionaron con la jefatura local:

"estando juntos, don Juan, cacique principal desta dicha provincia de Atacama, é Canchila é Cachagua, é Lequita é Lequitea é don Francisco é don Diego é Capina é Vildorpo é Capina é Vildopopoc é Catacata é otros muchos de sus principales é indios a él sujetos" (CDIHCH, 1888-1902, XXVIII: 73). 
Nada sabemos de las facultades ejecutivas y militares que esa docena de señores pudo ostentar, pero no es improbable que oficiaran como una suerte de instancia consultiva, aunque no estamos en pie de aseverar si ese pretenso cenáculo, si es que alguna vez llegó a reunirse efectivamente, rigió en fases de paz o de guerra. Almagro va a batirse, en consecuencia, no con precarias unidades consanguíneas adormecidas y dispersas entre sus ayllu ancestrales, sino con una etnia en forma y relativamente cohesionada en torno a adalides señoriales aptos para movilizar las energías sociales y diseñar una estrategia de hostilización perdurable.

La dominación inca, impuesta unos 70 años antes del advenimiento de la primera hueste hispana, (Rowe 1966), no derivó en la desintegración de la Cultura San Pedro, que preservó la continuidad intestina bajo la supremacía cusqueña (Bittmann et al. 1978). La expansión incásica en la región atacameña encontró abertura en una primera irradiación cultural de "tono" pacífico, que allanó la penetración imperial posterior (Latcham 1938; Le Paige 1968); planificando en el siglo XV DC mediante un desborde perpendicular surgido en el mesosistema altiplánico meridional, sujeto ya al Tawantinsuyo (Llagostera 1976; Santoro 1983).

No fue en verdad ni cruenta ni enfática (Garcilaso 1609; Serracino 1974; Llagostera 1976). Se ha supuesto al régimen cusqueño la gestación de un consenso pacífico entre etnia y Estado que posibilitó un control hegemónico indirecto, basado en una política aliancista con la dirigencia étnica local, predispuesta a tal entendimiento como secuela de su antigua militancia en el tráfico multiétnico y en la trama de complementariedad ecológica vigente con sus ecozonas de interacción respectiva de la periferia andina (Bittmann et al. 1978; Núñez y Dillehay 1979).

En buena parte, esa exitosa política de vinculaciones conducida por la élite atacameña, que en la postrera fase preinca centralizó su gestión rectoral en el Pucara de Quitor (P. Núñez 1982), responde a la acertada conversión de la perseverante estructura de nexos culturales, principalmente con el altiplano y el Noroeste Argentino, en un factor de consolidación política del enlace interseñorial, sin que, por ello, las contribuciones etnoculturales externas dislocaron radicalmente la composición autónoma del proceso atacameño (Bennett 1946; Le Paige 1960; Orellana 1963; Núñez 1965; Willey 1971).
Por cierto, prevalecen, forzosamente, el modelo lingüístico y el canon ideológico cultista del Tawantinsuyo, tanto como la tripartición predial y la mitad estatal. Pero el Estado omitió la ocupación militar desmesurada, así como la gestión autoritaria de un corpulento núcleo funcionario, enfatizando más en la regulación económica de enclaves productivos preeminentes (Aldunate y Castro 1981), entregada a una somera burocracia asentada en los tampus regionales (Lynch 1977), la cual parece privilegiar más la gestión minera (Bird 1977-78) que la agrícola, dueña, esta ultima, en el momento de la irrupción incásica, de fronteras agrarias en expansión (Stehberg 1974).

La cautivación cusqueña comportó un impacto aculturativo de derivaciones disociantes en el plano linguístico y en la esfera ideológica, al tiempo que una franca manipulación de la energía productiva local, canalizada institucionalmente a través de la mit' $a$. Pero no es menos verdad que una pluralidad de formas vernaculares quedaron tenuemente afectadas por la impronta incásica, incluso exentas de ella. La exigua incidencia que las artesanías arquetípicas del Tawantinsuyo proyectan sobre los padrones estilísticos locales es un consistente indicador de que nos encontramos ante un proceso aculturativo de impacto menos disolvente que el afirmado por los pendolistas castellanos (Serracino 1974; Núñez y Dillehay 1979).

La reclasificación política decretada por el régimen cusqueño tuvo, al parecer, lindes estrechos, en cuanto no fueron aplastadas ni las autoridades ni la élite territorial. Antes bien, los líderes étnicos prosiguieron, al parecer, en posesión de aquellas dispensas y privilegios tradicionales sobre sus territorios étnicos que no contradecían el programa incásico (Núñez y Dillehay 1979), concesión que no constituía uso inusitado en el Imperio (Murra 1976).

Esta articulación flexible entre etnia y Estado en el marco circumpuneño no sugiere la disolución de la autoridad y regulación política del segundo entre la pluralidad de señores naturales locales. El rostro del Estado se expresa en la inserción convencional de la élite autoritaria lugareña a su propia estructura de dominación, que legitima su continuismo social y le procura una alta prosapia nobiliaria, destinándola a oficiar como instancia de control intermedio que dinamiza la articulación entre Estado y sociedad y, desde luego, asegura la dependencia de ésta respecto del primero.

Los altos dignatarios atacameños quedaban sujetos por lazos de dependencia y reciprocidad con el soberano 
o con el Estado, que de paso tonificó la capacidad de los señoríos comarcanos para forjar nexos estables como etnias distantes (Hidalgo 1982a), y canalizar, mediante este expediente, el flujo de bienes activados por el control multiecológico local. Pese a lo anterior, el hervor de la Cultura San Pedro prosiguió latente bajo la superestructura institucional que levantó sobre ella el Estado inca. Una vez que en el desastre de Cajamarca perdió Atahualpa su cetro y al Imperio, aquella terminó por desmoronarse con él.

Al igual como ocurrió en parte de la periferia territorial incásica, en la que varias de las etnias sometidas vieron ocasión de recobrar autonomía (Llorente 1862), la nación Atacama discurrió por un breve período en que relajó su articulación política con el Estado y, probablemente, los señores naturales que no declinaron todas sus prerrogativas de poder bajo tutela cusqueña volvieron a ejercitarlas, sin restricción externa, en sus territorios étnicos privativos.

Los castellanos que fatigaron el desierto juzgaron con ligereza que sus naturales debían la greda, el maíz y los dioses al Tawantinsuyo y, de consiguiente, imputaron a un puro acto de fidelismo político hacia el Imperio, que entraba en la muerte, las tenaces guerras que aquellos encendieron a su paso. En esto son unánimes el cronista y el caudillo hispano. Algo de verdad alienta bajo esa convicción, pues cabe asignar al emisariado despachado por el Inka Manco II, hacia las provincias del Imperio, parte de la responsabilidad en la instigación de las insurrecciones comarcales de 1536 y 1540.

Nosotros postulamos, sin embargo, que a ese proceso lo anima un desiderato más vasto. Hidalgo ha acreditado con rigor que la hegemonía cusqueña no fue grata a la etnia local (Hidalgo 1978); no obstante su flexibilidad, la primera supone el receso de la autonomía política y la alineación de la esfera ideológica nacional, al tiempo que la improntación de un modelo productivo coercional basado en la demanda continua de servicios adicionales y la permanente tributación al Imperio de energía humana local, así como la regulación estatal de la propiedad predial y la transferencia constante de riqueza productiva corporativa, expresada en los excedentes agroganaderos apropiados anualmente por el Estado.

A su vez, la densidad demográfica y el espaciamiento telúrico de los oasis subandinos tornaban propensas a sus poblaciones nativas a detentar un alto grado de emancipación social y espacial, que el dominio supranacional cusqueño, inexorablemente, debía constreñir. No será ajeno a este antagonismo interétnico latente y aplazado durante setenta años el que los guerreros de Atacama hostiguen con esmerada crudeza a la servidumbre peruana que sigue la estela de las huestes españolas en posición de asistentes (Hidalgo 1978). Con todo, en 1536 se adscribieron de hecho a la insurrección pluriétnica que recorrió el área meridional andina luego del cerco instaurado por el Inka Manco contra el Cusco, lo que movió a los prosistas peninsulares a postular que, en este punto, los ejércitos atacameños se redujeron a cumplir la interdicción previa del Inka. Sin desdecir del todo esa conjetura, sospechamos que las insurrecciones distritales conllevan designios más indispensables.

No descontamos que los emisarios del Inka laboraron pacientemente los ánimos a la espera del instante positivo de contundir de un golpe unitario el dominio ibero en Perú; el impulso final de la dinámica resistencial atacameña, creemos, emana de la franca aversión a las secuelas disociantes que informan la conquista hispana.

Los dirigentes señoriales de Atacama gozaron en los cuatro años que distancian a Cajamarca de Almagro del tiempo necesario como para noticiarse del corolario desestructurante que la cautivación ibérica dejó entre las sociedades aborígenes de la esfera circuncusqueña, y más allá de ésta para abandonarse a la esperanza de que era plausible encontrar puntos de tangencia en el contenido axiológico de ambos universos de cultura. El colonialismo hispano, con su orientación mercantilista e inspiración ético-señorial subordinada a las imposiciones de la expoliación guerrera, amén de su confesionalismo intransigente y la vocación por la despropiación violenta, no podía afianzar sus propias instancias de dominación sin desestructurar y subrogar la precedente contextura organizacional indígena.

Con la dominación inca fue hacedera la gestación de un consenso bipartito que mitigó la dependencia y posibilitó la prórroga de su contenido orgánico, conciliación que no resultaba viable frente a las directrices empíricas asumidas por la española.

"Los incas permitían cierto margen de libertad -puntualiza Hidalgo- y por ello pudieron ser tolerados, pero desde sus primeros contactos con los españoles percibieron todo lo que significaba para su modo de vida el sometimiento a los intereses 
europeos. No era lo mismo depender políticamente que no alteraban sus formas tradicionales de vida, que de una sociedad con un desarrollo y marcos culturales completamente distintos como la española" (Hidalgo 1978:36).

La conquista peninsular solo permitía ser acatada o resistida. Resolvieron lo segundo; contaban con un ejército que ha sido cifrado entre 700 y 1000 almas, un sistema fortificatorio que el interregno inca dejó intacto, trojas bien provistas de excedentes con que nutrir a sus guerreros y la solidaridad de una geografía que hacía del ámbito valluno una ínsula difícil de abordar. Por demás, en las medianías de 1536, las parcialidades de Tarapacá se encontraban ya sobre las armas, habiendo aniquilado la colonia hispana de Pica (Oviedo 1557).

Almagro y la nativa belicosidad de la nación atacameña escribieron más tarde el resto.

\section{Entre los logros y frustraciones (1536-1540)}

Acaso uno de los rasgos sustantivos de la conquista castellana de Atacama es la de responder, al menos en su origen, más a un acto de azar que al resultado natural de una meditada voluntad, según lo refrenda el destino final de la expedición que Almagro acaudillara hasta Chile, pasaje que instaura el proceso de penetración europea en el despoblado.

Por de pronto, ejercemos la libertad de abordar rectamente el único episodio que nos compete de la tentativa almagrista, sin conceder semblanza de sus andanzas precedentes ni de los motivos que lo determinaron a declinarla. Nuestro clasicismo historiográfico ha restituido con holgura unos y otros como para evitarnos fatigar nuevamente ese preámbulo.

Ya es bastante conmemorar el desventurado pie en que se debatía la división ibérica en las medianías de 1536. A la sazón, se encontraba disipada entre la mesnada del Mariscal la seducción de Chile y, por cierto, la señorial divagación que les movió a vislumbrar en sus comarcas el "segundo" Perú del mediodía. El retorno de Gómez de Alvarado de la incursión de guerra hasta los pluviosos bosques de los promaucaes, además del arribo de refuerzos en deplorable condición, terminó por abatir sus postreras esperanzas.

La concisa cuota aurífera incautada, las aldeas desperdigadas, un invierno recio, los brazos fluviales vadeados bajo lluvias desbocadas y el cerco perpetuo de indios que primero abasaban sus sementeras y más tarde disputaban cerradamente cada ápice de territorio, eran motivaciones lo bastante apremiantes como para alentar en adalides y soldados una perentoria añoranza de regreso. Ese designio primó finalmente en Almagro que, constreñido por el clamor unitario de la hueste, ordenó el retorno a Perú.

En septiembre de 1536, el grueso de la división inició el regreso a Copiapó, hasta donde confluyeron también las rezagadas columnas de Rodrigo Orgóñez y Juan de Herrada, este ultimo con las prescripciones reales que otorgaban a Almagro la posesión del Cusco. La resolución de rehacer el sendero a la capital citadina del Imperio inca, cogiendo la ruta de Atacama y no la cordillerana estaba tomada al salir de Aconcagua, decisión que las penurias soportadas por los últimos refuerzos arribados por esa vía terminaron por respaldar.

Desde Aconcagua, despachó Almagro hacia el litoral atacameño a Francisco de Noguerol con 80 hombres de a pie y de a caballo, con el mandamiento concluyente de abrir los jagüeyes y los manantiales que bordeaban la ruta interna del desierto, reunir los bastimentos elementales y afianzar la "seguridad de aquella provincia, que estaba de guerra" (Oviedo 1557: cap. V, pp. 243-244). ${ }^{2}$ El mandato del adelantado era lo bastante categórico como para que Noguerol se atuviera a habilitar las aguadas desérticas "después de pacificar la dicha provincia" (Oviedo 1557: cap. V, pp. 243-244). Oviedo avanza que, a más del auspicio incásico, la rebelión atacameña adelantó debido al exterminio de una facción ibérica que marchaba en pos de la hueste expedicionante en Chile.

"La causa del alzamiento fue haber muerto algunos cristianos de los que en seguimientos del adelantado iban, é asimismo por mandado del Inga que, como paresció, estaba alzado dando guerra a los españoles de toda la tierra" (Oviedo 1557: cap. V, p. 247).

¿Con cuáles fuerzas vincular a estos hispanos? Por cierto, no con lanzas de Ruy Díaz, al que en alguna oportunidad se le imputó haber consumado la travesía del Despoblado, supuesto que Sergio Villalobos invalidó sólidamente. Tampoco con gente de Orgóñez o Herrada

2 Lo anterior basta para impugnar la convicción de Amunátegui (1885: 98) que atribuyó esas providencias de Almagro al deseo de precaver ataques de indios ultracordilleranos. 
que ingresaron a comarca chilena por vías andinas. $\mathrm{Si}$ el pretenso episodio efectivamente llegó a ocurrir, es probable que involucrara a un corto rezago castellano obstinado a alcanzar a la brigada almagrista cogiendo la ruta del pasillo árido, sendero que las restantes columnas residuales en principio desdeñaron.

Almagro anduvo certero, inclinándose por soluciones que, vistos los embarazos que más tarde le opondría el desierto, parecen sensatas. Recabó de caciques e indios de Copiapó noticias pertinentes al trayecto del despoblado, reunió el maíz y ganado suficiente, acopió agua y avanzó breves descubiertas de hispanos y de negros, provistos de azadones a objeto de abrir los manantiales del intermedio desértico (Oviedo 1557: cap. V, p. 245). Sólo cuando esta misión se encontraba encaminada, lanzó a su hueste a desafiar el despoblado. Al tiempo que su división se batía con el erial fraccionado en cortas partidas, el Mariscal Almagro, último hispano que salió de Copiapó, se adelantó hasta los valles de Atacama, en donde sus tenientes tenían reunido algún maíz y ganado, únicamente para palpar que Noguerol y Orgóñez, el que también remitiera previamente con una avanzada, no habían dado cabal cumplimiento a su ordenanza de someter el distrito atacameño.

"Y mediando el mes de Octubre, se hallo con su teniente Rodrigo Orgóñez que le habia enviado adelante, en el pueblo principal de Atacama, el cual y el capitán Noguerol, que antes del por la mar había ido desde Chile, hallaron la tierra alzada é de guerra, y la gente por los montes, fuera de sus casas é asientos, y puestos en montañas y sierras muy ásperas, puestos que no se podían sojuzgar" (Oviedo 1557: cap. V, p. 247). ${ }^{3}$

Fue preciso abrirse paso a espada en demanda del maíz y el alimento remanente ocultos, en medio de feroces asaltos de los indios que, desperdigados en facciones entre la fronda comarcana, emboscaban a las columnas castellanas o degollaban a los yanaconas peruanos.

El grueso de los indios de guerra, que al parecer no disfrutaron de un concurso bélico significativo de las fuerzas incásicas (Santa Cruz 1913), acantonaron en el Pucara de Quitor, patrocinados por la cruda geografía valluna conspiraba en contra de una holgada

\footnotetext{
3 Testimonio que rescinde las conclusiones de Barros Arana (1884, vol. 1, p. 198), quien, pretendiendo haberse sustentado en Oviedo, invalida toda posibilidad de experiencia resistencial en este punto.
}

batida de pacificación (Bibar 1558). La guerra de vacío vino a reunirse a esa contrariedad, de suerte que los peninsulares, puestos ante la masiva ausencia de las unidades filiales, se vieron impedidos de incorporar violentamente a la población distrital a las partidas de servicio, al igual como lo hicieron profusamente en Copiapó (Molina 1968).

La hueste hispana, amén de la falta de yanaconas y de aliados, vio incrementarse sus bajas y el anillo indígena. Francisco de Aguirre refrendó más tarde que en los entreveros las facciones insurgentes "mataron al dicho Adelantado un español cuando volvió de esta provincia y... salían a saltealles al camino a robar é a matar los que venían desmandados" (CDIHCH, X, Primera declaración de Servicios de Francisco de Aguirre: 16).

Habida cuenta de que su división iba a Atacama por holganza y no de guerra, quiso el Adelantado omitirle el desgaste de una contienda local de pacificación, decretando un certero ataque a Quitor, a objeto de decidir en un solo acto de guerra el levantamiento provincial. Envió con ese mandato a Orgóñez y cien lanzas de caballería hasta el reducto, pero el teniente ante la imposibilidad de asaltar a caballo las ventajosas posiciones que ocupaban los indios, se vio forzado a desmontar a sus hombres y realizar una arremetida pedestre, la cual derivó en una derrota vergonzante, que obligó a Orgóñez a ordenar el repliegue, vistos que, apunta Francisco de Riveros, "le descalabraron ciertos españoles é que dio la vuelta porque no lo pudo tomar" (CDIHCh, X: 21).

Luis Ternero, uno de los que militó en el asalto, brindó una reseña más elocuente en la que confesó haber ido "en seguimiento de los indios para los castigar y que llegaron allí y no los pudieron entrar a los dichos indios que allí se habían fortalecido y se volvieron" (CDIHCh, X: 35).

Tras esa derrota fue preciso defender a espada el corto trecho que ocupaba el real de los indios envalentonados, que no cejaron sus ataques en los 18 días que los peninsulares reposaron en Atacama. Consumado ese plazo, salió la hueste almagrista en demanda de Perú, dejando la demarcación atacameña entregada a los alzados y a los dispersos señoríos regionales en virtual insurrección; eventualidad que el Mariscal, obstinado en restituirse el Cusco, escasamente parecía inquietar.

El propio Luis Ternero epilogó atinadamente las desventuras de Almagro en Atacama: "sabe é vido 
este testigo, que los dichos indios de Atacama é otras provincias no quisieron salir de paz al dicho don Diego de Almagro, antes estaban de guerra" (CDIHCh, X: 35).

Acaso por un secreto sarcasmo del mismo acontecer, cuatro años más tarde la vigorosa insurrección atacameña fue transitoriamente abatida por un tenue fragmento de la hueste castellana que en seguimiento de Valdivia pasó hacia Chile en 1540.

Desterraremos de antemano aquellas peculiaridades de la empresa de Valdivia ajenas a nuestro propósito temático. A la sazón, únicamente haremos caudal de la participación del destacamento regido por Francisco de Aguirre, el cual determinó ligarse a la expedición de Valdivia junto a los 25 hombres que bajo su mando acantonaban en la Provincia de Chichas por delegación de Diego de Rojas, tras su desventurada incursión a los chiriguanos.

Bien se recordará que Valdivia, con el fin de aumentar la precaria hueste que, luego de seis meses de apresto, lograra convocar y sacar del Cusco decidió hacer gente proclamando un bando en el Collao, Charcas, Tarija y Porco, que reclamaba hombres de armas para su ejército, a los que dio alternativa de agregársele fuera de Tarapacá o en Atacama (CDIHCh, X: 15-16).

De toda suerte, conforme la brigada de Valdivia ingresaba al dominio sudista de Perú, varias facciones peninsulares, sobrevenidas desde el Collao, e integradas mayoritariamente por tercios que no eran sino el saldo humano de las difuntas aventuras castellanas de la ceja selvática del naciente andino, se orientaron hacia Tarapacá, evitando Atacama, que se encontraba todavía en pie de insurrección (Bibar 1558, cap. VI: 12).

Sólo la carta descubierta de Aguirre se inclinó a aguardar a Valdivia en esta ultima, abandonando en marzo de 1540 la Provincia de Chichas, en procura del Distrito de Atacama, al que arribaron en abril del mismo año.

Según conjetura de Hidalgo, Bibar imputó erróneamente a Valdivia hechos cumplidos por Aguirre en esta marcha (Hidalgo 1972: 29). Si esa sospecha es certera, la magnitud política de los mismos excedió los lindes del despoblado, toda vez que un cuantioso ejército chicha fue deshecho por Aguirre en su descenso hacia la fresca guirnalda de Atacama (Bibar 1558, cap. VI: 13), evento que algunas opiniones barruntan como una emergente estrategia contraeuropea, bosquejada por la élite rectora de las jefaturas de Chichas y Atacama (Núñez y Dillehay 1979), etnias latitudinalmente cercanas. ${ }^{4}$

Como sea, los guerreros de Aguirre no encontraron reposo al término de su camino: no bien escurrió la estrecha escuadra peninsular entre la orla forestal de Atacama se presentaron los ejércitos señoriales a disputarles la posesión del paisaje. "Todo este dicho tiempo que estuve esperando al dicho señor Capitán Pedro de Valdivia -evocó posteriormente Aguirre-, los naturales de la dicha provincia me dieron siempre guerra" (CDIHCh, X: 16).

Casi cotidianamente fue apremiada la fuerza castellana por una guerra de emboscadas (Guevara 1925; Thayer 1929), detrás de la cual los capitanes creyeron vislumbrar siempre la intangible silueta del Inca.

"El día en que entre en la dicha provincia tomé un pueblo entero é les hablé a todos los indios é indias que se tomaron y les dije que se fuesen a su cacique y le dijesen que no hubiese miedo é viniesen de paz a los cristianos, porque todas las provincias sujetas al Inca los servían, y que ellos no podían dejar de servillos, pues estaban repartidos y no eran muchos, como los demás indios que en las otras provincias habian" (CDIHCh, X: 16).

La respuesta estaba pronunciada mucho antes que Aguirre invocara ese discurso. Los altos caudillos señoriales, por mediación de sus pares guatacondinos, caperuzones y piqueños, habían ya obtenido noticia de que se aproximaban españoles, a los que recibieron con las familias ocultas, sepultados los cereales, algarrobos y chañares, abrasadas las sementeras y con los guerreros del país plantados en la breña y recintos de lidia (Rosales 1670; Bibar 1558).

Si bien la congregación indígena en espacios sellados fue la conducta privilegiada por el proyecto táctico local, las directivas nativas alentaron, al mismo tiempo, el hostigamiento fraccionado, mediante

4 No obstante, ya es bastante decidor que ni Aguirre ni los testigos que declararon sus méritos en las rendiciones de servicios a la corona hechas por el primero, nunca citen esta presunta batalla librada contra un grueso ejército chicha, entre los hechos memorables que marcaron su trayecto desde Chichas hasta Atacama, pormenor que, considerada su magnitud cuantitativa, debió al menos concitar una ligera referencia. 
breves escuadras aborígenes que, noche con noche, descendían hasta la fronda desde los baluartes cerreños, a objeto de acosar a la servidumbre peruana que corría la tierra en busca de suministros con que sustentar a sus patronos iberos (Bibar 1558).

Aguirre, que gozaba de mayor golpe de vista táctica y de mejor estrella que Almagro, en corto tiempo ganó aliados entre los mismos indios comarcanos, los cuales pronto le enseñaron el sitio exacto donde ocultaban las trojas con las cosechas (Bibar 1558); a lo que vino a unirse una esmerada emboscada nocturna que le permitió aniquilar a las partidas rebeldes que lo constreñían.

Evaporado definitivamente el anillo aborigen, pudo el jefe hispano entregarse a meditar con tiento el asalto a Quitor, bastión asentado en los sesenta metros de un cerro que apoyaba con sus verticales escarpes la defensa de ambas alas del reducto (Latcham 1938), custodiado, en cómputos de Bibar, por más de mil rebeldes (Bibar 1558). A principios de junio, empleando el grueso de su partida compuesta por quince jinetes y diez infantes entre ballestas y arcabuces, ${ }^{5}$ emprendió el asalto del reducto en el que, cabe sospechar, militó también una cuantiosa facción de indios auxiliares que jamás nominó en sus probanzas de servicios. ${ }^{6}$ El avance fue demorado hora y media por la flechería y las piedras de los indios, que provocaron las mayores bajas y requiebros entre los castellanos que buscaban la altura; pero, no bien tocaron éstos la cintura mural del bastión giraron la batalla en su favor (CDIHCh, X: 39; Bibar 1558; Rosales 1670).

Una brecha concedió entrada a los iberos que terminaron por conquistar el recinto en una recia batalla al arma blanca. Parte de la guarnición quedó en el campo "é otros -acota Francisco Hernández, soldado de Aguirre-, se despeñaron huyendo" (CDIHCh, X: 39).

El líder hispano manchó su victoria ordenando degollar, sin fronteras de linaje, a principales e indios de la masa cogidos en batalla, cuyas cabezas, colgadas

5 Bibar (1558) lo fijó en 30 hombres; Rosales (1670) en 50 y el mismo Aguirre (CDIHCh, X: 16) en nueve de un total que no excedía los 25 .

6 Thayer (1929) postula que en dicha circunstancia reside la facilidad con la cual Aguirre consumó sus tareas de pacificación en el ámbito septentrional, intencionalmente innominadas a fin de autoexceder su propia valía militar. para escarmiento de rebeldes, recibieron, días más tarde, a los rezagados tenientes que seguían la estela de Valdivia (CDIHCh, X, Declaración de Rodrigo de Araya: 63; Le Paige 1965).

El conquistador de Quitor blasonó en sus probanzas de servicio de haber mantenido domeñada la región al arribo de Valdivia, resultado que, digamos de paso, fue aliando en parte por el canon estratégico conservador adoptado por la dirección militar indígena, además de la crisis de cohesión y el disenso intestino en que se debatía la sociedad local, expresado en la gestación de pautas de colaboracionismo nativo, vastamente manipulado, en su favor, por la jefatura castellana.

Las propias medidas que los adalides peninsulares promovieron en tanto descansaron en Atacama y que apuntaron a aplastar el descontento y la conspiración interna entre sus hombres, más que a la hostilidad indiana, parecieron otorgar crédito a la versión de Aguirre (Proceso de Valdivia, 1873: 49, 50, 68, 69, $81,82,93,94,107,108)$.

Como quiera que fuese, los guerreros emanados con Valdivia desde Tarapacá desdijeron al prócer de Quitor. Era fama entre esa gente que en Atacama hallarían tierra de contienda, convicción que los hechos postreros no desmintieron (CDIHCh, XII: Probanza de Méritos y Servicios de Santiago de Azoca: 36). En Tarapacá habían tenido ocasión de comprobar la mengua del vigor resistencial de las dispersas etnias locales, incapaces de resucitar el cénit insurgente de 1536 (CDIHCh, XIV: 472-483; XXI: 240; XXII: 59-62; XXIII: 200, 230, 232, 510, 555). Pero que el encaje verde de Atacama era, de momento, el intermedio bélico de mayor respeto en la calzada desértica que se desborda al norte de Copiapó, no demoró en ponderarlo Valdivia apenas salvó el sur de Pica, al contemplar cómo los comarcanos retomaban la guerra de vacío, ocultándole agua y suministros (Valdivia 1550).

Contrariamente a lo establecido por Aguirre, los hombres de Valdivia testifican que los señoríos seguían de guerra, las aldeas en abandono y el alimento oculto; el que fue menester despojar a los indios mediante saqueos armados por partidas españolas que debieron buscarlo a tres, cinco o más leguas del real (CDIHCh, XII: Probanza de méritos y servicios de Santiago de Azoca: 36, 51, 52, 60, $69,86,98,105,114,123,132,141)$. 


\section{La voluntad de persistir}

A despecho de los supuestos de Silva (1904), que atribuyce a Francisco de Aguirre la definitiva pacificación de Atacama, la proeza de aquel sólo derivó hacia el quiebre momentáneo de la hasta esa hora sostenida ofensiva insurgente en el intermedio árido. El capítulo que prosigue señala que este episodio fue sucedido por unos quince años de guerra comarcana.

El año siguiente del paso de Valdivia, sorprendió al cacique de Atacama comprometido conspirativamente, desde la distancia, con sus iguales del Mapocho en un plan desestabilizador del reciente asientamiento hispano ( $\mathrm{CHCH}$, Actas del Cabildo de Santiago, Libro Becerro, 1: 76). De otro lado, no bien abandonó la hueste de Valdivia el distrito ancestral, tornaron sus naturales a la condición de indios de contienda, hostigando a los viajeros hispanos que fatigaban la ruta del Perú a Chile, de tal suerte que estos últimos, detallan los pendolistas coloniales, buscaban omitirse peligros, absteniéndose de transitar por los oasis atacameños, estimados "territorios de guerra" (Herrera 1601, CHCH, XXVII: 505; Marino de Lovera 1595, CHCH, VI, Lib. I, cap. XIII: 85).

Alonso de Monroy, en el arduo viaje que emprendió hacia Perú en 1543, por cuenta de Valdivia, debió salvarlos con recato (Olivares CHCH, IV, Lib. II, cap. VI; Rosales 1670, I, Lib. III, cap. XIV: 401), e incluso a su retorno en 1543, se vio forzado a conquistarles el paso a las partidas atacameñas, junto a las 70 lanzas que le seguían (CDIHCh, Probanza de Servicios de Cristóbal Escobar, XII: 251, 268, 295).

Poco detalle resta de la guerra que los atacama libraron entre el paso del Mariscal Valdivia y la capitulación de 1557, pero se postula que su sombra cubrió constantemente el contenido de esa fase.

Francisco Altamirano, remembrando los méritos de su padre, Juan Velásquez Altamirano, en la probanza que rindió en 1596, confiesa que este domeñó el ímpetu de las insurrecciones locales "habiendo estado los indios de Atacama veinte i dos años de guerra y alzados y que habían muerto muchos españoles y que impedían con fuerza de armas el camino de Chile" (Probanza de Juan Velásquez Altamirano, Corregidor de Atacama y de su hijo Francisco Altamirano, AGI, Charcas, Leg. 80 1596: f. 3, en Hidalgo 1982b).
Esa amenaza al tramado comunicacional hispano se vio acentuada por alianzas bélicas longitudinales, selladas por los directivos étnicos locales con las parcialidades de Tarapacá y Copiapó.

La travesía de Valdivia favoreció peculiarmente la perfilación de alianzas estratégicas con las etnias de Copiapó, orientadas a restar apoyos logísticos, cancelar trayectos y hostigar a los destacamentos castellanos que buscaban el meridión (Bibar 1558). Una variante de la reciprocidad militar contemplaba la aniquilación de los últimos previa comunicación despachada desde Atacama; la columna que Diego de Maldonado condujo a Copiapó en 1547, sufrió ese epílogo (Valdivia 1550); en tanto que la que Pedro de Villagra acaudillara desde Perú en 1549, abordó este valle, tras batirse en la ruta y romper un cerco indio en Chañaral (CDIHCh, Probanza de Servicios de Juan Jufré, XV: 25, 34, 45, 52, 108, 141, 172).

Pero el liderazgo virreinal no medió rectamente en el asunto hasta cuando los hechos posteriores aconsejaron adoptar un programa consistente frente a la emergente actividad insurreccional en el despoblado, si no quería poner en compromiso la permanencia de la contextura comunicacional que la vinculaba a las jurisdicciones del mediodía, principalmente con la de Chile.

Con todo, el Estado virreinal perseveró en su conducta abstencionista respecto a la responsabilidad militar del proyecto reducionista, transfiriendo esa tarea, mediante acto delegatorio, a fuerzas subalternas. Puso en obra este propósito comisionando la pacificación de Atacama al licenciado Altamirano, oidor de la Audiencia de Lima, el que a su vez traladó el mandamiento a su hermano, Juan Velásquez Altamirano, viejo protagonista de las contiendas civiles de Perú (CDIHCh, XXVIII: 73-74).

Los dignatarios virreinales se hallaban a esa altura puntualmente ciertos que las rebeliones nativas en el piemonte puneño se habían nutrido, en parte, de las expoliaciones y rancheadas practicadas por las expediciones castellanas en tránsito hacia Chile (Villalobos 1980), como para que demandaran a Velásquez obrar con tiento en su cometido.

Del proceso militar que prosiguió no ha quedado rastro, salvo la declaración de Francisco Altamirano respecto al sesgo privado asumido por una empresa que Velásquez consumó "llevando sus amigos a la dicha 
provincia en que gastó mucha suma y cantidad de pesos oro" (AGI, Audiencia de Charcas, Leg. 80 1596: fol. 3, en Hidalgo 1982b). Velásquez no desdeñó el buen tacto $y$, por intermedio de lenguas e indios chichas, a principios de 1556, llamó de paz a don Juan, cacique principal de Atacama y a los caciques subalternos, participándoles las ventajas que obtendrían en cuanto al tutelaje de sus derechos étnicos, de convertirse al evangelio y acatar la voluntad regia.

Acompañó esta iniciativa con una misiva personal cuyos destinatarios eran los hispanos en tránsito hacia Chile, en la cual les demandaba cancelar las rancheadas contra los comarcanos, ahora sujetos al servicio del Monarca y de la Iglesia. Tanto este expediente como el celo que gastaron las directivas peninsulares por menguar los actos expoliatorios, dieron, de momento, resultados auspiciosos. El mismo don Juan testificó que "había pasado mucha gente que iba a Chile é habían visto las dichas cartas é no les habían hecho molestia alguna, ni ellos asimismo habían hecho daño en los tales españoles" (CDIHCh, XXVIII: 77).

La contracción ostensible de los procedimientos coercionales dio paso a una transición de tono necesariamente más indulgente, al menos lo suficiente como para alentar a don Juan y a sus principales a presentarse en la aldea de Suipacha a gestionar directamente con Velásquez, a la sazón en Potosí, los términos de una avenencia. No demoró Velásquez en converger hasta Suipacha, portando donativos para los caciques convocantes, además de la reiteración de su promesa de brindar protección monarcal a las prerrogativas señoriales y al patrimonio indigenal, pero condicionando esta ultima a la inmediata supresión de la iniciativa insurgente en los valles subandinos.

Su conducta en los días siguientes, cortés pero consistente, llevó a los dignatarios indígenas hasta la convicción de que estaban reducidos a la disyuntiva de deponer las armas o perpetuar el movimiento resistencial, con proyecciones cada vez más sombrías para el destino final del partido aborigen. Los honorables señoriales prefirieron debatir la oferta en concilio interno, trámite que no los absorbió vastamente, inclinándose, finalmente, por acogerla y conceder, de paso, un testinomio espontáneo de sinceridad, requiriendo para el efecto el bautismo cristiano, acto que el padre Hernán de la Piedra concluyó por oficiar, tras el consenso de Suipacha, distrito de Chichas (CDIHCh, XXVIII: 77).
Hurtado de Mendoza proveyó la conmutación jurídica de los caciques interdictos en cuanto éstos participaron su dictamen,

"teniendo entendido que no tenían culpa por causa de haberlo hecho en defensa y amparo de sus personas é haciendas é por obviar las fuerzas é robos que los españoles les habían querido hacer... por la presente viniendo vos é vuestros principales é indios que con vos andan alzados, de paz al servicio y obediencia de $S$. M., vos perdono en su real nombre, ansí del alzamiento que habéis tenido como de cualesquier daños, muertes, robos é otras cosas que hayáis hecho é cometido desde el día que os alzastes hasta que, como dicho es, vengáis de paz" (CDIHCh, XXVIII: 74-75).

El 5 de marzo de 1557, en el pueblo principal de Atacama se cumplió la liturgia de rendición, por parte de los líderes señoriales, que donaron simbólicamente a Velásquez arcos, flechas y demás armas que mantuvieron veinte años en contienda, al tiempo que eran saludados por las trompetas de plata y arcabuces de los hispanos presentes en el ceremonial, al cual una misa vertida en kunza por el presbítero Cristóbal Díaz de los Santos quiso hacer más decoroso.

\section{Entre la inconstancia y el término (1557-1590)}

La fase que media entre 1557 y 1590 denota que una cosa era la instauración jurídica de la paz y otra su consolidación. En principio, el factor de inestabilidad más poderoso continúa siendo, paradojalmente, la guerra misma. Bien es cierto que las paces de 1557 decretaron un interregno que facultó a los hispanos de La Plata a jactarse en 1561, que por el camino de Atacama "queriendo benir o yr por ferra puede ir un hombre o dos seguros en cuarenta días" (AGI, Charcas 1561, Leg. 31, doc. 6).

Mas, pronto se quebró el reposo del desierto y en 1563 ya se prevenía en el Perú que en la ruta de los despoblados que conducían a Chile, imperaba el indio de contienda (JLPB, I: 560). Desconocemos los detalles elementales del nuevo capítulo insurreccional -que más parece un proceso discontinuo de levantamientos que una perseverante guerra de resistencia-, excepto la evidencia de que varias rutas fueron hostigadas y algunos castellanos asesinados en su entorno (AGI, Charcas 1596, Leg. 80, f. 4, en Hidalgo 1982b). 
Los rasgos de la nueva experiencia insurreccional sugieren, sin embargo, que ésta conforma un despliegue fragmentario el cual responde más a un esfuerzo sectorial que a un impulso plenario del cuerpo social nativo. No es improbable que desde una perspectiva endocultural la afirmación del modelo hegemónico peninsular resultara en un impacto aculturativo cuya secuela disociativa no sólo se palpa en la pérdida de cohesión intraétnica y debilitamiento de la compleja organización indígena, sino también en las controversias desestructurantes que agitan a las cúpulas indígenas menguando su capacidad de gestar movilizaciones orgánicas del conjunto corporativo.

No es un contrasentido, por tanto, el que varios señores apoyados en partidas residuales pudieran promover inconstantes períodos de alzamientos, matizados con otros de inmovilismo que las memorias historiales del virreinato se ocuparon de recordar. La de 1583 acentuó reveladoramente el sesgo de ambigüedad que asume la conducta política de la sociedad atacameña, de la cual se consignan su deficiente inserción en el sistema clasificatorio colonial, además de su fluctuante voluntad que discurre entre las riberas del acatamiento y las de la guerra (JLPB, I: 181).

Un año después la corona adelantó que la resultante práctica de esa cadenciosa estrategia de alzamiento continuaba siendo la recurrente inhabilitación del acceso a Chile (ACMP, Sección Cajas Reales, Potosí, vol. 46 1570-1591, fs. 176-177). La dinámica insurreccional atacameña, no obstante, siguió condicionada a impulsos inorgánicos (Lizárraga 1968) que invalidan, en lo que resta, la recomposición de un proyecto sociopolítico unitario y representativo de resistencia.

Sólo contados observantes veían en ellos indios de guerra hacia 1590:

"De Atacama a Copiapó [establece en ese año el Licenciado Cepeda, oidor de la Audiencia de Charcas...] en todo cual camino no hay pueblo de españoles y por tener en sus confines indios idólatras de guerra y no ser ellos muy de paz, ha sucedido muchas veces haber muerto muchos españoles que de este reino al de Chile han ido por tierra y de estas dos provincias son el receptáculo de todos los indios que de esta provincia se huyen $y$ si se poblase evitárase todo esto" (MSM, 90: doc. 1257).
Sin duda, conforma una imagen distorsionada por la distancia. Preferimos la que trazan, en el propio corregimiento de Atacama, hombres como Agustín Mondragón que, por la misma época, testimonia: "questos indios son pacíficos y que al día de oy lo están muy mucho y questo lo save porque a estado entre ellos y vivido entre ellos de mas de veynte años a esta parte y que decir que son belecosos y de guerra ques falsedad y mentira (ANB, Charcas, 1. $\left.417, \mathrm{~s} / \mathrm{n}^{\mathrm{o}} 1590\right)$.

No desdicen esa convicción los memoriales de guerra laborados en el Reino de Chile a fin de siglo que señalaron al Despoblado de Atacama, distrito sometido (MSM, 250, Doc. 7352).

\section{Conclusiones}

Una primera evaluación del evento resistencial atacameño postula que sus logros, observados en lo que concierne a su capacidad de neutralizar los desarrollos coloniales en el marco circumpuneño, son más relativos que absolutos. Desde luego interfieren, pero no impiden el contacto interdistrital hispano y su dinámica de transferencias; y análogo resultado obtiene el proceso de hostigamiento y presión sobre la estructura político-institucional generada por la corriente ocupacional europea. Muchos son los rasgos que delatan la precariedad de los resultados indígenas en este punto.

Si bien la hostilidad aborigen aplazó más de lo esperado la afirmación de la sede política peninsular (San Pedro), aquella no evitó que desde el primer instante de la Conquista esa aldea escenificara, de modo transitorio, eventos políticos trascendentes (Gay 1844), o que retuviera el carácter de intermedio logístico perenne para las empresas españolas que se orientaban hacia el mediodía (JLPB, 1: 562). A estos hitos se adjuntan aquellos que únicamente podían advenir con la maduración del asentamiento europeo. Quizás, si de estos últimos, los más notorios sean el otorgamiento que en 1560 el Marqués de Cañete hizo en favor de Velásquez Altamirano de dos repartimientos indígenas en la comarca y la incorporación en tiempo del virrey Castro, de Atacama, en calidad de corregimiento autónomo al conglomerado de 12 corregimientos aborígenes establecidos en Charcas al momento de decretarse la fragmentación provincial de Perú (AGI, Charcas, 1. 101; Relación Anónima sobre los Corregimientos de Perú, Colección del Risco, 330-122, $\mathrm{n}^{\circ}$ 10, Biblioteca Universitaria de 
Sevilla). No resistimos la seducción de sumar a los anteriores, aun a vía de ejemplo, la regularidad que parece alcanzar el relevo jerárquico en los niveles de cúpula (ALCPO 1922, I: 317) o la acentuación de la racionalidad en la organización espacial, que la consolidación de enclaves de control como Toconao suponen (AGI, Charcas 1596, 1. 80: f. 4, en Hidalgo 1982b).

De uno y otro no puede disociarse la feliz consumación de la expansión eclesial que alternó el quehacer misional con cierto proselitismo político, lo que, en último término, legitimó la estructura de dominación y allanó, alternativamente, la sujeción de focos regionales de fricción (Casassas 1974); recurso instrumental que, en cierta medida, los ejes de poder del virreinato tempranamente integran a su programa reduccionista del ámbito preandino de la Puna (JLPB, XI:4-5).

Las demandas primarias del sistema colonial son, aparentemente, más asequibles al procedimiento analítico, particularmente aquellas que entroncan con el requerimiento de constituir una vialidad expedita en el despoblado. Los peninsulares aceptan el lance que proponen los indios, en buena cuenta, por la exigencia de preservar un eslabón telúrico primordial para su dinámica de tráfico y contactos coloniales en el árido pasillo del poniente andino. De allí proviene el imperativo que los ibéricos se autoimponen en orden a mantener la apertura de la vía atacameña y de sus apoyos logísticos anexos, mediante la fundación de una estructura política congruente (Corregimiento) en un contexto de insurgencia aborigen.

Ciertamente, lo anterior no responde por sí solo las interrogantes que motivan un proceso ruptural también impulsado, en alguna medida, por el designio de encuadrar en su propia institucionalidad económica el potencial productivo local, considerando que los bienes y las formaciones étnicas de Atacama despiertan temprana codicia entre las huestes hispanas (Orellana 1964). A despecho de lo expuesto, cabe asentir que la irrupción inicial, en términos productivos, no optimizó los rendimientos agroganaderos tradicionales de la economía de oasis que, vistas la cuantía y potencial pecuniario de su estrato tributario, no logró sustentar un desenvolvimiento significativo de la encomienda (Lozano Machuca 1580). Lo propio ocurre si reactualizamos el análisis de las relaciones cuantitativas que pueden establecerse en lo que concierne a la ocupación efectiva del espacio valluno, dadas las bajas densidades demográficas europeas vigentes en el mosaico subandino. En consecuencia, es de rigor interrogarse respecto a la factibilidad de verificar en el marco atacameño un equivalente legítimo del impacto irruptivo colonial en aquellas economías andinas integradas al modelo de complementariedad multiecológica, en los términos propuestos por Murra (1976); atendiendo que varias de las comunidades agrarias de Atacama mantienen acceso autónomo a sus espacios productivos, incluso con la injerencia autoritaria del componente cacical (Bennett 1946).

Una pregunta espontánea conduce a propiciar un examen globalizante de la suerte que corre la contraparte indígena, directamente damnificada por la anexión hispana. La primera contrariedad que encuentra un análisis de este tipo proviene de la imposibilidad de practicar una mensuración adecuada del impacto colonial en términos cuantitativos debido a la notoria carencia de fuentes específicas. Ignoramos las cifras reales a que alcanzó la población atacameña, salvo estimaciones que a falta de datos confiables echan mano de procedimientos aproximativos, los cuales muestran un amplio espectro de oscilación. Así, el volumen absoluto ha sido cifrado con flexibilidad, arrojando computos que fluctúan entre 2800 y 4000 almas en el siglo XVI (Núñez y Dillehay 1979; Villalobos 1980; Hidalgo 1982a), estimaciones, por cierto, meramente inferenciales considerando que una buena fracción de la población nativa permaneció incensada. Cabe presuponer una contracción demográfica motivada por las bajas de guerra, migraciones, sistemas laborales y epidemias (Guevara 1925), aun cuando resulta impracticable una estipulación exacta de su monto o frontera cuantitativa.

En rigor, el reflejo aculturativo peninsular se manifestó en resultados asimétricos. El dominio lingüístico no experimentó coartaciones radicales en lo que respecta a su práctica ecuménica, pese a que la formación aborigen asimiló el español prontamente y otro tanto puede aseverarse en la esfera costumbrista. El universo ideológico vernacular, así como su aparato ceremonial adjunto, se encontró sometido, fuera de toda duda, a presiones más inmediatas por parte de la ideología dominante y de sus exponentes institucionales, aunque los avances alcanzados por esta última deben conceptuarse más como realizaciones formales que modificaciones sustanciales del patrimonio espiritual de la entidad aborigen. 
El proceso aculturativo hispano, sin embargo, debió transmitir paulatinamente su influjo disolutivo a tal punto que una buena proporción de modos y prácticas sociales, incluyendo los referentes axiológicos de la sociedad natural, se encontraban bajo abierta amenaza e, incluso, en franca mutación en la segunda mitad de la centuria.

La conformación sociológica y productiva debió soportar análogos embates, aunque en este ámbito topamos con los mismos embarazos que la ausencia de una base documental sólida fijada al examen cuantitativo, por lo que forzosamente debemos soslayar aquí el análisis de la dislocación de la base económica indigenal y de su sistema estratificatorio. En tanto no dispongamos de un caudal informativo elemental tocante a este tema, cualquiera proposición arribaría hasta divagaciones huérfanas de todo significado.

Por contrapartida, contamos con evidencia primaria en lo que toca a la presión desintegrativa que la maduración de la base institucional española ejerció sobre una cuantiosa parte del conglomerado natural; coacción que cobra expresión en la agobiante modalidad impositiva en que degenera la encomienda, órgano supeditado a la irrestricta manipulación de sectores dominantes, emergidos directamente de la coyuntura social que la gesta de Conquista instituye. Sin ir más lejos, Velásquez Altamirano se erige en elocuente exponente de esa tendencia al interior del contexto particular en el que le corresponde ejercitar su influencia caudillista. No quisiéramos cerrar este estudio sin referir algunos pasajes que figuran en el expediente judicial que se le siguió en 1590, a consecuencia de denuncia hecha en su contra por residentes españoles del partido y que, nítidamente, restituye la trágica condición del nativo local, sujeto a los nuevos poderes señoriales emergentes de la guerra. Escuchemos a Agustín Mondragón, quien exhaustivamente vino a testimoniar que Velásquez, "el Pacificador de Atacama":

"a tratado y contratado del puerto de la madalena ha potosi distrito deste coregimiento con ayuda de los yndios del dicho coregimiento y questando este testigo en la provincia de los lipis a visto pasar por ella pescado y preguntando este testigo... le dixeron los yndios quera del dicho $\mathrm{Ju}^{\circ}$ Velásquez Altamirano y que viniendo deste pueblo de atacama la grande encontró en el camino tres yndios desde dicho repartimito. que venían con ganado del dicho $\mathrm{Ju}^{o}$ Velásquez Altamirano los cuales dixeron a este testigo como avia mas de tres meses que avian salido de su tierra y que todo el dicho tiempo se avian ocupado en el servicio del dicho Ju Velásquez. Altamirano y que avian pasado mucha necesidad y la pasaban al presente de comida y preguntando este testigo si les pagava a ellos y a los demás yndios que se ocupaban en su servicio por jornales le respondieron que no les avi pagado" (ANB, Charcas 1591, 1.417, Sección Expedientes, s/n $\left.{ }^{\circ}\right)$.

Esta política no era excluyente, por cuanto integraba, además, a las bandas litoranas; el padre Francisco Bocos Cárdenas reveló:

"aver visto en el Puerto que por ynteres de tomarse los yndios para sus granjerios servirse de todos ellos como desclavos no quieren dar A ninguno de los que por aquella costa pescan yndio alguno ni que rescaten $i$ si el alguno les dan es primero haciendo concierto con el dicho Ju Velásquez. Altamirano que le bendan el pescado que pescaren al precio quel quiere $i$ questo es lo que save por averse hallo presente a algunos conciertos quel dicho $\mathrm{Ju}^{o}$ Velásquez ha hecho" (ANB, Charcas 1591, 1. 417, Sección Expedientes, $\left.\mathrm{s} / \mathrm{n}^{\circ}\right)$.

Las prestaciones forzadas consideraban servicios domésticos, lo que no dejaba de representar gravamen excesivo para los indios. El citado Bocos expresó saber:

"por cosa cierta i averiguada quel estar el dicho Juan velazquez con toda su casa... en este distrito es mui grande opresión para los yndios porque con el $i$ su familia están de ordinario en su casa ocupados una docena de yndios $i$ indias que save este testigo que de todo el repartimiento i camanchacas toda su diligencia y cuidado es recojer muchachos i muchachas para servicio de casa y que Por estas cosas $i$ otras no acuden a la doctrina como es raçon i que save este testigo que salido el dicho Juan velazquez con toda su casa los yndios quedaran alibiados acudirán a lo que al servicio de dios son obligados" (ANB, Charcas 1591, 1. 417, Sección Expedientes, $\left.\mathrm{s} / \mathrm{n}^{\circ}\right)$.

Renunciamos a continuar reproduciendo pasajes cuya única ventaja consistiría en sumar antecedentes a lo ya descrito. A lo más completaría ligeramente la imagen de un dramático acontecer cuya última raíz está más cerca del mundo surgido de la Conquista que de la simple germinación del sistema colonial avanzado. 


\section{Abreviaturas utilizadas}

AGI : Archivo General de Indias.

ANB : Archivo Nacional de Bolivia.

ACMP : Archivo de la Casa de Moneda de Potosí.

ALCPO : Audiencia de Lima. Correspondencia de presidentes y oidores.

CDIHCh : Colección de documentos inéditos para la Historia de Chile.

CHCh : Colección de Historiadores de Chile.

MSM : Manuscritos de la Sala Medina.

JLPB : Juicio de Límites entre Perú y Bolivia.

\section{Fuentes manuscritas}

AGI : Audiencia de Charcas, legs. $31 \mathrm{y}$ 101.

ANB : Audiencia de Charcas, expedientes, leg. 417.

ACMP : Cajas Reales, vol. 46.

MSM : Manuscritos inéditos de José Toribio Medina, vols. 250 y 290.

BUS : Biblioteca Universitaria de Sevilla, Colección del Risco, 330-122.

\section{REFERENCIAS CITADAS}

ACTAS DEL CABILDO DE SANTIAGO, 1861, CDIHCh, vol. 1, Santiago.

ALCEDO y HERRERA, A., 1967. Diccionario geográfico de las Indias Occidentales. Biblioteca de Autores Españoles, Editorial Atlas, Madrid.

ALDUNATE, C. y V. CASTRO, 1981. Las chullpa de Toconce y su relación con el poblamiento altiplánico en el Loa Superior Período Tardío. Ediciones Kultrún, Santiago.

AMUNATEGUI, M. L., 1885. Descubrimiento y conquista de Chile. Santiago.

BENNETT, W., 1946. The Atacameño. Handbook of South American Indians, vol. 2.

BIRD, J., 1977-78. El hombre de cobre, un minero prehistórico del norte de Chile y sus herramientas. Boletín del Museo Arqueológico de La Serena 16.

BITTMANN, B., G. LE PAIGE y L. NUÑEZ, 1978. Cultura atacameña. Ministerio de Educación, Serie Patrimonio Cultural, Santiago.

BOMAN, E., 1908. Antiquités de la region andine de la République Argentine et du Desert D'Atacama. Imprimerie Nationale, París.

CASASSAS, J. M., 1974. La región atacameña en el siglo XVII. Datos históricos y socioeconómicos sobre una comarca de América meridional. Universidad del Norte, Antofagasta.

DE BIBAR, G., 1966. Crónica y relación copiosa y verdadera de los reynos de Chile. Santiago.

DE HERRERA, A., 1901. Descripción de las Indias y tierra firme del mar océano que llaman Indias Occidentales, $\mathrm{CHCh}$, vol. XXVII, Santiago.

GARCILASO DE LA VEGA, I., 1902. Comentarios reales. Colección de Historiadores de Chile y Documentos relativos a la Historia Nacional, vol. XXIX, Santiago.
GONZALEZ, A. R., 1963. Las tradiciones alfareras del Período Temprano del Noroeste Argentino y sus relaciones con las de las áreas aledañas. Anales de la Universidad del Norte 2.

GUEVARA, T., 1925. Historia de Chile. Chile prehispánico. Santiago.

HIDALGO, J., 1972. Culturas y etnias protohistóricas: Area Andina Meridional. Chungara 8.

1982. Fechas coloniales de fundación de Toconao y urbanización de San Pedro de Atacama. Chungara 8.

LATCHAM, R., 1938. Arqueología de la región atacameña. Prensas de la Universidad de Chile, Santiago.

LE PAIGE, G., 1960. Antiguas culturas atacameñas en la cordillera chilena. Revista Universitaria de la Universidad Católica de Chile.

__ 1965. San Pedro de Atacama y su zona. Anales de la Universidad del Norte 4.

_ 1968. Subárea atacameña. Actas del XXXVII Congreso Internacional de Americanistas vol. 2. Buenos Aires.

LEVILLIER, R., 1922. Audiencia de Lima. Correspondencia de presidentes y oidores, Madrid.

___- 1926. Nueva crónica de la conquista del Tucumán. Madrid.

LIZARRAGA, R. 1968. Descripción breve de toda la tierra de Perú, Tucumán, río de la Plata y Chile. Biblioteca de Autores Españoles, vol. 205. Editoral Atlas, Madrid.

LLAGOSTERA, A., 1976. Hipótesis sobre la expansión incaica en la vertiente occidental de los Andes Meridionales. Anales de la Universidad del Norte 10.

LOVERA, P. MARINO DE, 1867. Crónica del reino de Chile. Colección de Historiadores de Chile y Documentos relativos a la historia nacional, vol. 7, Santiago. 
LOZANO MACHUCA, J., 1885. Carta del Factor de Potosí Juan Lozano Machuca al virrey del Perú en donde se describe la Provincia de los Lipes. Relaciones Geográficas de Indias, vol. 2, Madrid.

LYNCH, T., 1977. Tambo incaico de Catarpe. Estudios Atacameños.

MOSTNY, G., 1948. Ciudades atacameñas. Boletín del Museo de Historia Natural 25.

1977. Prehistoria de Chile. Santiago.

MURRA, J., 1976. Los límites y las limitaciones del archipiélago vertical en los Andes. Anales de la Universidad del Norte 10 .

_ 1983. De la mit'a al Tawantinsuyo, prestaciones de los grupos étnicos. Chungara 10.

NUÑEZ, L., 1965. Desarrollo cultural prehispánico del norte de Chile. Estudios Arqueológicos 1.

NUÑEZ, L. y T. DILLEHAY, 1979. Movilidad giratoria, armonía social y desarrollo en los Andes Meridionales: Patrones de tráfico e interacción económica (ensayo). Universidad del Norte, Antofagasta.

NUÑEZ, L., V. ZLATAR y P. NUÑEZ, 1975. Relaciones prehistóricas trasandinas entre el Noroeste Argentino y norte de Chile (Período Cerámico). Documentos de Trabajo 6, Universidad de Chile, Antofagasta.

NUÑEZ, P., 1982. Significado del Pucara de Quitor, norte de Chile, Resúmenes del IV Congreso Internacional de Americanistas, Manchester.

ORELLANA, M., 1963: Problemas de la arqueología de San Pedro de Atacama. Anales de la Universidad del Norte 2.

— 1964. Acerca de la cronología del Complejo Cultural de San Pedro de Atacama. Antropología 2.

OVIEDO y VALDES, G. FERNANDEZ, 1902. Historia general natural de las Indias, islas y tierra firme del mar océano, CDIHCh, T. XXVII.

PONCE, C., 1976. Tiwanaku: Espacio, tiempo y cultura. La Paz.

ROSALES, D. DE, 1877. Historia general del reyno de Chile, 3 vols. Valparaíso.
ROWE, J. 1946. Inca culture at the time of the Conquist. Handbook of South American Indians, vol. 2.

SANTA CRUZ, J., 1913. Los indigenas del norte de Chile antes de la conquista española. RChHG, vol. 7, Santiago.

SANTORO, C., 1983. Camino del Inka en la Sierra de Arica. Chungara 10.

SERRACINO, G., 1974. Cerámica de Guatin. Estudios Atacameños 2.

_ 1979. Relaciones interregionales en los Andes Meridionales 1000-1200 DC. XLIII Congreso Internacional de Americanistas, Vancouver.

——Proposición de una organización política en el Período Tardío en la Provincia de El Loa, II Región de Antofagasta. Resúmenes VIII Congreso de Arqueología Chilena, Valdivia.

SILVA, O., 1980. Culturas y pueblos de Chile prehispánico. Santiago.

SILVA, L., 1904. El conquistador Francisco de Aguirre. Santiago.

STEHBERG, R., 1974. El complejo estructural de Guatin. Estudios Atacameños 2.

TARRAGO, M., 1968. Secuencias culturales de la etapa agroalfarera de San Pedro de Atacama (Chile). Actas del XXVII Congreso Internacional de Americanistas, vol. 2.

1976. Alfarería típica de San Pedro de Atacama. Estudios Atacameños 4.

THAYER, T., 1929. Francisco de Aguirre. Santiago.

VALDIVIA, P. DE, 1939. Cartas de Pedro de Valdivia. Sevilla.

VASQUEZ DE ESPINOZA, 1948. Compendio y descripción de las Indias Occidentales. Smithsonian Institution, Washington D. C.

VILLALOBOS, S., 1980. Historia del pueblo chileno. Santiago.

WILLEY, G., 1966. An introduction to American archaeology. Prentice Hall, Englewood Cliffs, Nueva Jersey.

ZARATE, A. DE, 1901. Descubrimiento y Conquista del Perú. CHCh, vol. XXVII, Santiago. 